\title{
Effects of Pilot Injection Timing on the Engine Performance of a Diesel Dual Fuel Engine
}

\author{
Jose da Silva ${ }^{1}$, Dori Yuvenda² ${ }^{\text {, Bambang Sudarmanta }}{ }^{1}$
}

\begin{abstract}
The combustion process in dual fuel diesel engines occurs sequentially starting with premix burning. The premix burning starts with the ignition delay process. The presence of CNG causes the ignition delay process to become longer, thereby reducing engine performance and increasing emissions on dual fuel diesel engines. This study uses diesel engine type Diamond DI 800 with dual fuel indirect injection model system. The method used a variation of diesel pilot injection timing $110 \mathrm{CA}, 130$ CA, 150 CA, 170 and 190 CA BTDC. Testing is done with a constant engine speed of 1500 rpm and loading 500 to 3000 watts with 500-watt intervals. The results show that by advancing the diesel pilot injection timing where brake horsepower and the average effective pressure between single fuel and dual fuel is not too far as the current and voltage changes generated by the generator are not too small. While optimal thermal efficiency increased by $\mathbf{4 . 1 1} \%$, while CO and HC emissions decreased respectively by $\mathbf{1 0 . 8 5 \%}$ and $8.28 \%$ at occurred at the pilot injection timing 170 CA BTDC but still under the single fuel engine.
\end{abstract}

Keywords_—Diesel Pilot Injection Timing, Thermal Efficiency, Carbon Monoxide, Hydrocarbon

\section{INTRODUCTION}

$\mathrm{T}$ he technology that promises to be used in internal combustion engines is dual fuel or dual fuel systems. Diesel fuel diesel engine is a diesel engine that added fuel gas in the intake manifold or directly to the combustion chamber and ignition is carried out by diesel spray [1], [2].

The combustion process in the Diesel Dual Fuel (DDF) engine occurs sequentially wherein the first stage there is premix burning of the pilot fuel. In the premix combustion process, the pilot begins with an ignition delay process. Ignition delay is the time from the start of the initial period of diesel injection (start of injection) to the start of combustion (start of combustion). Stage ignition delay there are two parts namely; first physical delay, where this period occurs atomization, evaporation, mixing between fuel and air. Second, chemical delay where this period of chemical reactions start slowly and then accelerate the formation of fire spots. Currently, the technology of fuel entry systems developed in DDF engines is a mixer, low pressure and high pressure [3]. Theoretically, the more efficient type of dual fuel system used is a Low Pressure (LP) model, because reducing $\mathrm{CNG}$ is wasted. Where the CNG is supplied only after the suction valve is opened and the exhaust valve is closed so that gas fuel supply is more efficient. Also, this type also requires a cheaper cost than other types. The low-pressure system using diesel and CNG fuels has decreased engine performance by $65 \%$ average thermal efficiency reduction against single fuel [4], [5].

The pilot injection timing will effect on engine performance, combustion process, cylinder pressure, HRR, thermal efficiency and emission formation.

\footnotetext{
${ }^{1}$ Jose da Silva, and Bambang Sudarmanta are with Department of Mechanical Engineering, Institut Teknologi Sepuluh Nopember, Surabaya, 60111, Indonesia. E-mail: josepayaharanomoko@gmail.com; bsudarmanta@gmail.com.

${ }^{2}$ Dori Yuvenda is with Department of Automotive Engineering, Universitas Negeri Padang, Padang, 25171, Indonesia. E-mail: doriyuvenda@ft.unp.ac.id.
}

To improve engine performance by advancing diesel pilot injection time can affect the speed of burning diffusion slower $45 \%$ compared to premix burning stage. Taken and the rate of heat release increased and a significant decrease in $\mathrm{CO}$ and $\mathrm{HC}$ emissions and increase NOx increases [6], [7].

Based on the description and the above research can be concluded that by advancing the diesel pilot injection timing can affect the ignition delay thus affecting engine performance.

\section{METHOD}

The test is done by an experimental method on Diamond DI 800 diesel engine, with the main shaft which has been directly coupled with an electric generator, figure 1 . This machine will be modified into dual fuel by using diesel fuel and natural gas type compressed natural gas (CNG). The test was conducted into 2 (two) groups, namely diesel engine using single fuel with diesel fuel as a control group, and diesel engine using dual fuel system with combination fuel of diesel fuel and CNG as a test group. To get combustion performance when diesel pilot injection is done variation at the angle or diesel pilot injection timing by adding a shim on packing injection pump holder. Lights as loading on the machine. The lamp consists of incandescent lamps as much as three pieces with power consumption of each lamp of 500 Watt. The lights are arranged in parallel on a board with each lamp equipped with a contact for setting the light load. The engine modification process and the whole series of tests were conducted at the Fuel Laboratory and Energy System, Department of Mechanical Engineering, Institut Teknologi Sepuluh Nopember Surabaya. Thus the authors conducted an experimental study on diesel diamond type DI 800 diesel engine, one cylinder, which is operated by dual fuel solar-gas CNG. The method used is setting diesel pilot injection time of 110CA, 130CA, 150CA, 170CA and 190CA BTDC under 
variation load. Engine speed $1500 \mathrm{rpm}$ and loading 500 to 3000 watts with 500-watt intervals. Modified angle change can be done in two ways by giving or reducing torque on fuel injection pump bolt, and adding or reducing shim in the fuel injection pump. Other angle changes can be made by addition of shim, also can be done with torque firming on the fuel injection pump bolt. Changes made to reduce volume and change the angle of fuel injection on diesel motors. This modification made the addition and reduction of $0.1 \mathrm{~mm}$ thick shim between fuel injection pump and seat and will change by $1^{\circ} \mathrm{CA}$.

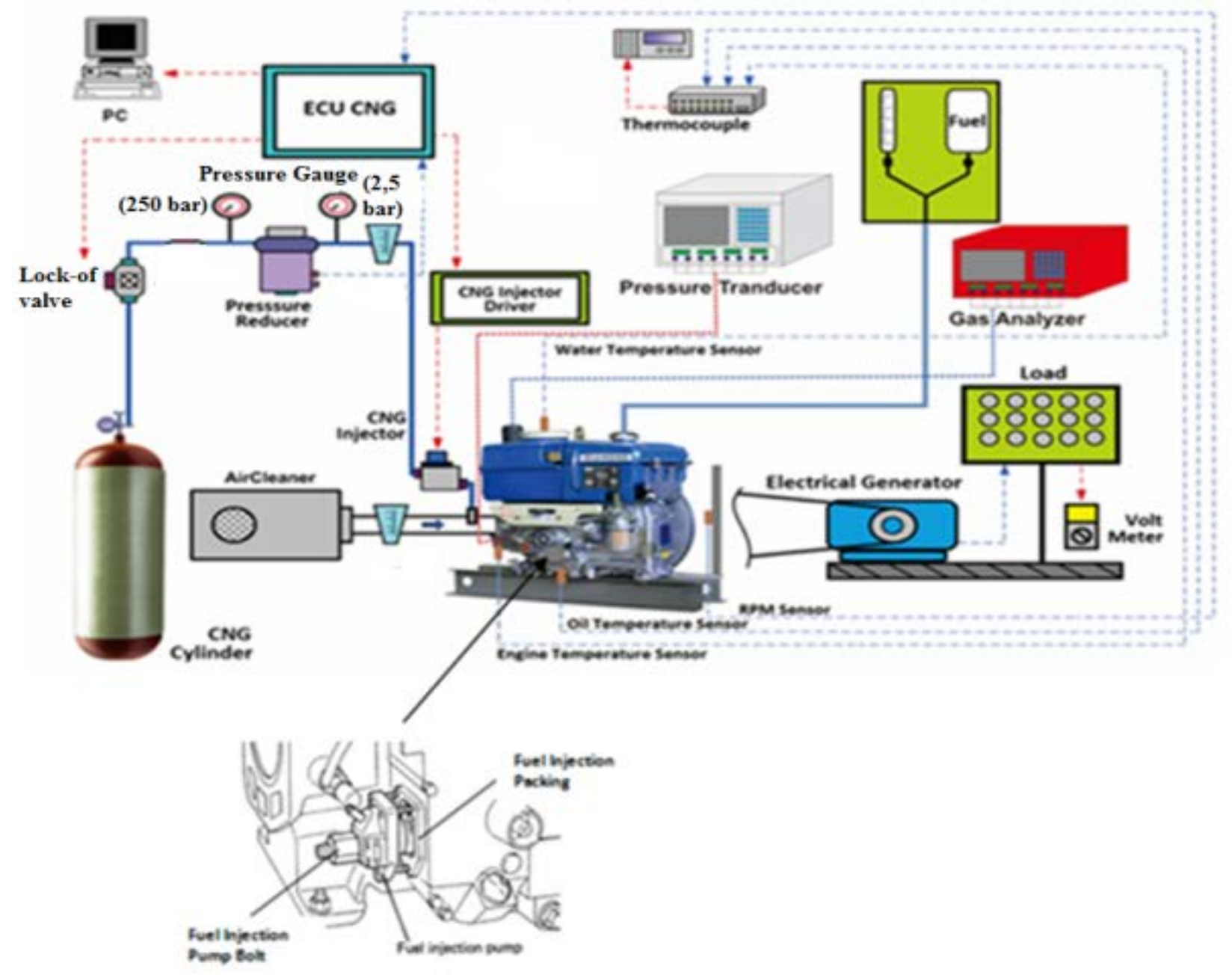

Figure 1. Experimental setup.

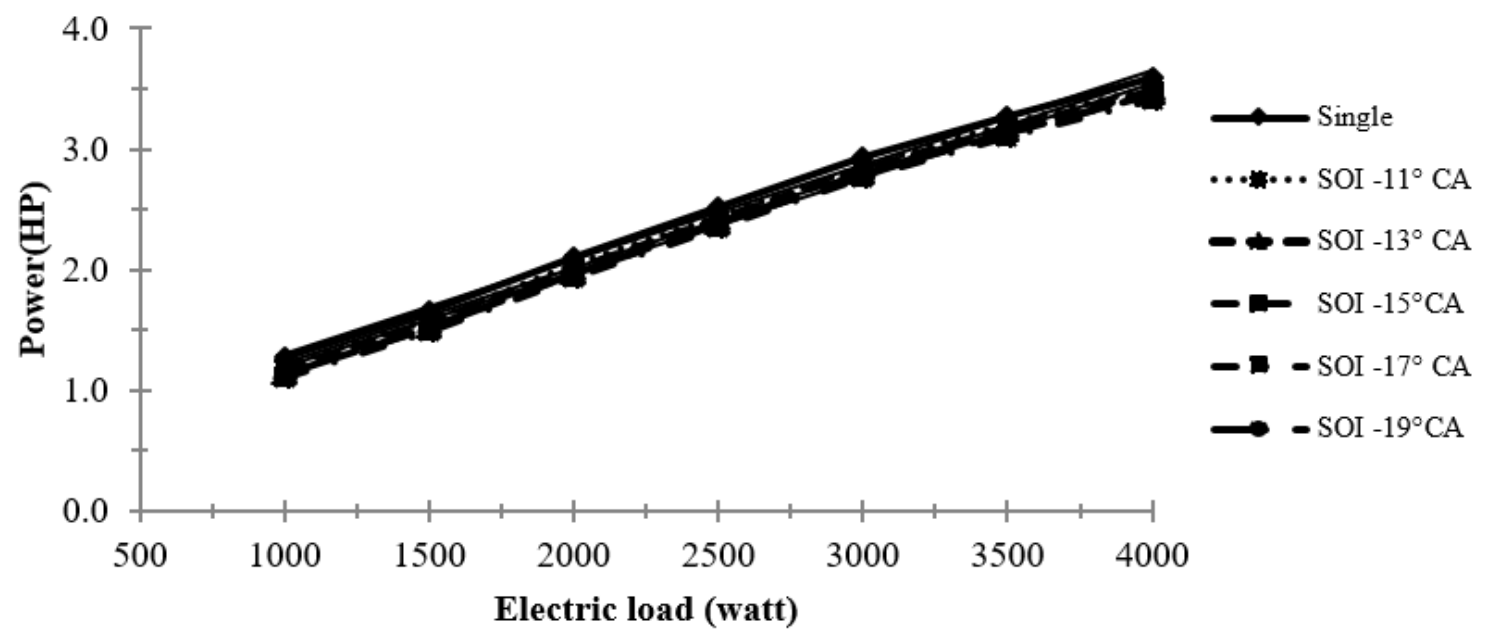

Figure 2. Power versus electrical load. 


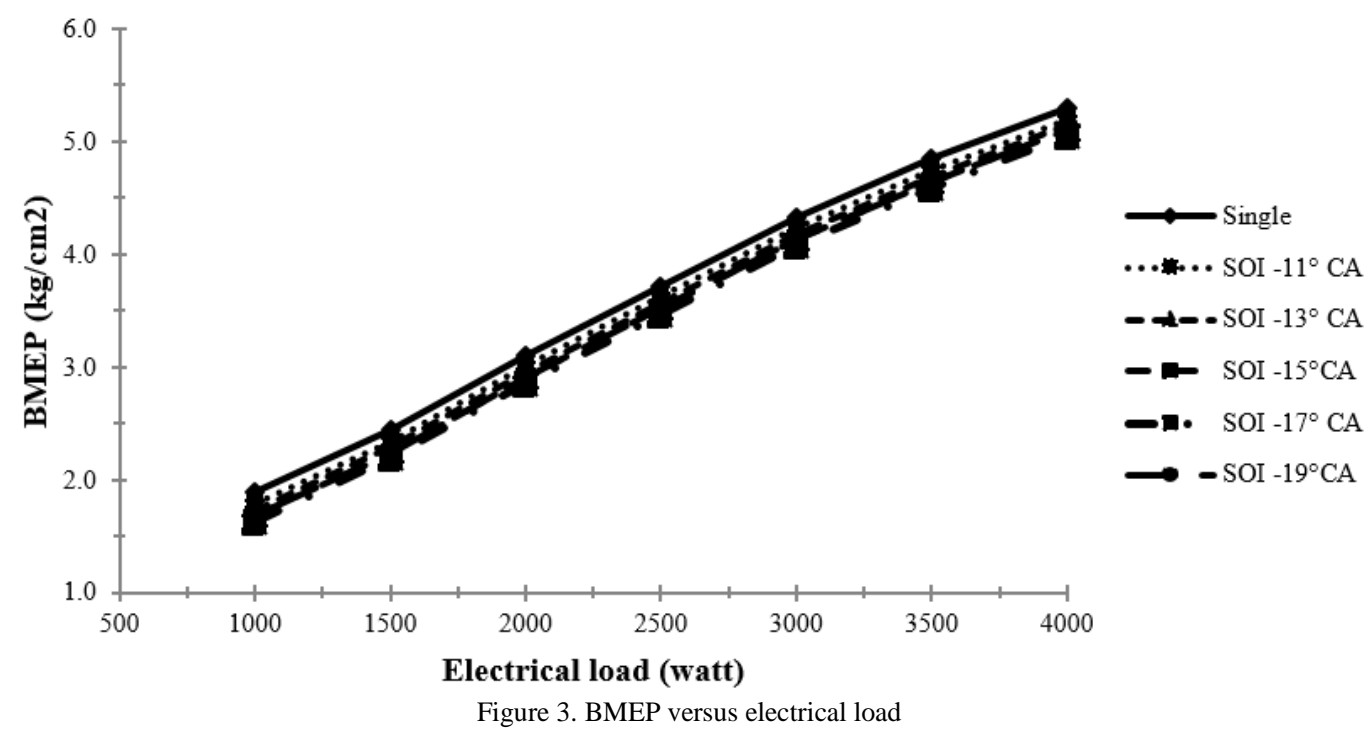

\section{RESULTS AND DISCUSSION}

The tests were conducted on single fuel diesel oil and dual fuel diesel oil and gas (CNG) systems. Before testing the dual fuel system, a single fuel oil test is used to obtain the initial data as a reference/standard to see the parameter changes that occur during dual fuel system implementation.

\section{A. Horse Power (Ne)}

The addition of load from 1000 watts to 4000 watts generator has decreased the voltage, and the rotation of the diesel engine also decreased. To keep the diesel engine spin stable, so the throttle on the engine is adjusted so that the throttle lever connected by the governor provides the diesel supply to overcome the overload received from the generator. So the engine revolves back up, and generator rotation also rises. Figure 2, shows the power of the load function where the required power increases with increasing electrical load and as compensation for the increase of fuel entering the combustion chamber. Increasing fuel causes more energy to convert into heat and mechanical energy with enough air. Energy makes the engine power greater by the load given to the machine by the advancing the diesel pilot injection timing to increase the engine power with increasing load, but still under single fuel.

\section{B. Brake Mean Effective Pressure (BMEP)}

The BMEP of the piston is the constant pressure acting on the piston and produces the same work. The more fuel that is detonated in the combustion chamber, the greater the expansion pressure generated will result in increased BMEP as the load increases.

Advancing SOI and CNG injection duration provide a more homogeneous mixing process, and combustion in the combustion chamber will make the BMEP generated even greater. The increased in load causes a change of air and fuel mixture towards a rich and poor mixture - the more fuel that is blasted, the greater the expansion pressure. Figure 3, shows the average effective pressure load function, which regarding the phenomena occurring within the engine, the increase in load will cause the AFR (air-fuel ratio) change toward the fuel-rich mixture. Advance the beginning of the diesel fuel injection and provide increased BMEP feed load. The more fuel that is blown up in the combustion chamber, the greater the expansion pressure it produces.

\section{Thermal Efficiency}

At the time of single fuel use, high thermal efficiency and then at the CNG mass flow rate presented by the magnitude of $70^{\circ} \mathrm{CA}$ injection duration there was a decrease in thermal efficiency. This is due to the magnitude of input energy through a larger fuel in dual fuel for the same load. The graph shows that the maximum thermal efficiency for dual fuel on diesel pilot injection timing -17O CA ATDC.

Figure 4, shows the graph thermal efficiency function load. Thermal efficiency on dual fuel systems decreased by $44.04 \%$ compared to single fuel. From the variation of the diesel pilot injection timing and the duration of CNG 70 CA injection shows the best of thermal efficiency occurred on diesel pilot injection timing $17^{0} \mathrm{CA}$ BTDC. As the pilot injection timing increases and the fuel-mixing time is more homogeneous. The combustion time and the amount of CNG fuel are sufficient to allow the fuel mixture and more combustion air where the resulting combustion energy is greater. Fast burning rates as more air mixes and burning fuels also generate thermal energy efficiency $\left(\eta_{\text {th }}\right)$ will increase. The relationship between the SFC and the resulting thermal efficiency value illustrates that as the SFC drops to its lowest thermal efficiency rises to its maximum value. As the value of SFC rises again the thermal efficiency value falls which indicates more fuel is wasted due to combustion gas.

\section{Carbon Monoxide Emissions (CO)}

Figure 5, Shows graph of carbon monoxide emission (CO) of electric load function tends to compose. Carbon monoxide in dual fuel systems increased $75 \%$ compared to single fuel. 


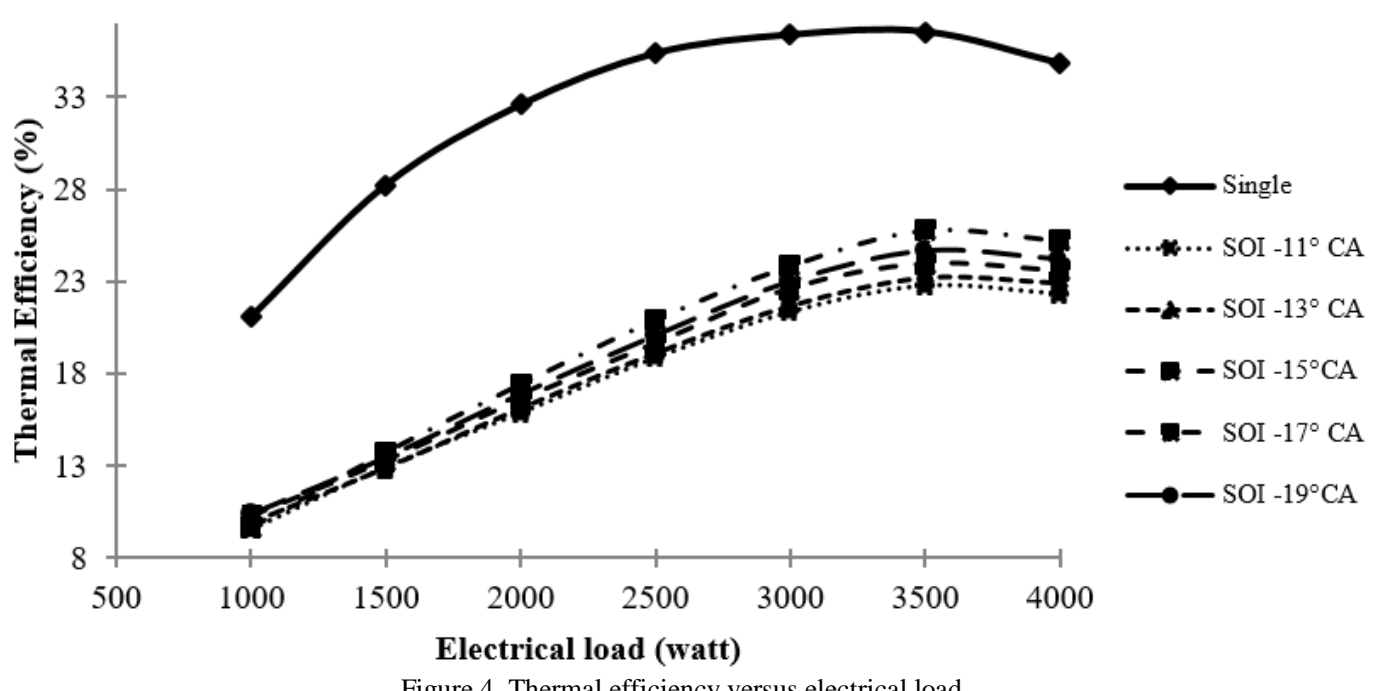

Figure 4. Thermal efficiency versus electrical load.

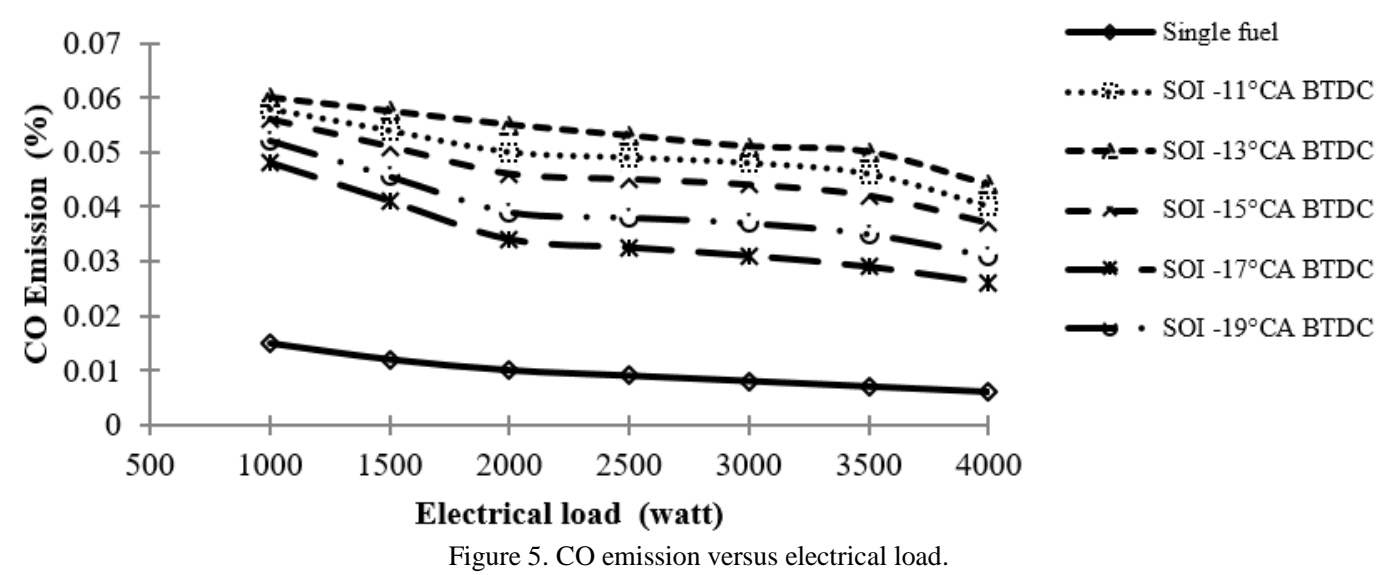

Advancing the diesel pilot injection timing on the system dual fuel decreases $10.85 \%$ positively affects (i.e. decreases) $\mathrm{CO}$ emissions at $17^{0} \mathrm{CA}$ BTDC. This allows fuel distribution to start of burning more early against top died centre with this resulting in the maximum increase in temperature that supports $\mathrm{CO}$ formation. However, at the same time increasing time intervals during the expansion phase where high temperatures persist in the cylinders it can affect positively on $\mathrm{CO}$ oxidation so that more $\mathrm{CO}$ mass is formed. And it may also be caused by that the dual fuel burning phase is heavily controlled by pilot injection timing and advanced pilot injection timing leads to the previous combustion phase. Also, more mixtures are incorporated in the combustion process, and the heat release rate is increased by advancing the diesel pilot injection timing. As a result, the cylinder temperature increases, which may be the main reason $\mathrm{CO}$ decreases.

\section{E. Hydrocarbon Emissions (HC)}

In Figure 6, shows the value of $\mathrm{HC}$ emissions is almost the same for all CO but decreases with the load. The hydrocarbon emissions in dual fuel systems increased by $44.17 \%$ compared to single fuel, when advancing the diesel pilot injection timing at $17^{0} \mathrm{CA}$ BTDC occurred the $\mathrm{HC}$ emission decreased by $8.28 \%$. HC Emission decreases when the injection timing is advanced, which allows optimizing engine performance while maintaining lower HC emissions.

Further diesel pilot injection time, HC decreases, and above single fuel, this may be because the dual fuel combustion phase is heavily controlled by the diesel pilot injection timing given the electrical load and the continued pilot injection time leads to the previous combustion phase. Also, more mixtures are incorporated in the combustion process, and the heat release rate is increased by advancing the pilot injection time. As a result, the in-cylinder temperature increases, which may be the main reason for decreasing HC emission.

\section{F. Particulate Matter (PM)}

Figure 7, Shows the emission of PM load function. The addition of the load then the PM emissions rise both in the dual fuel system and single fuel. However, compared to the single fuel system, there was $68.29 \%$ reduction in PM emissions in the dual fuel system, this is because substitution of CNG gas fuel replaces $100 \%$ diesel fuel, thus reducing smoke. Advancing the diesel pilot injection timing occurred PM emission increased by 9.03\%. At each variation, the PM value increases with increasing load. This is because fuel injection can reduce the amount of fresh air in the combustion chamber to reduce the concentration of oxygen which causes the temperature in the combustion chamber to decrease. 


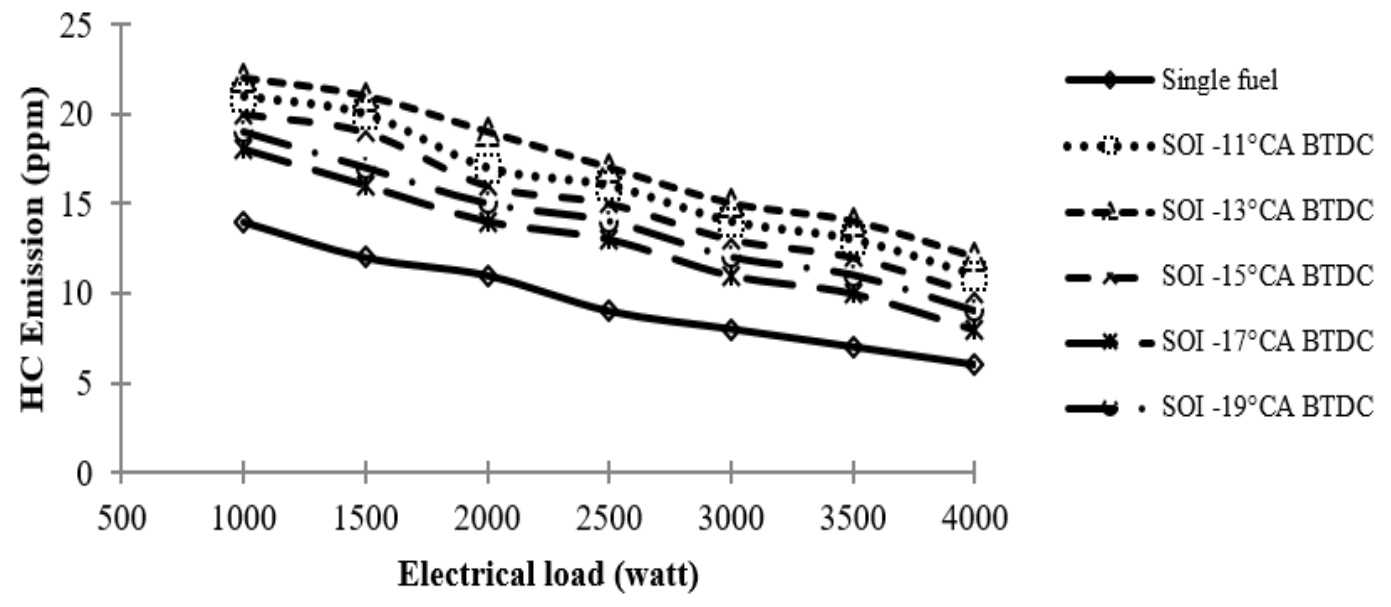

Figure 6. HC emission versus electrical load.

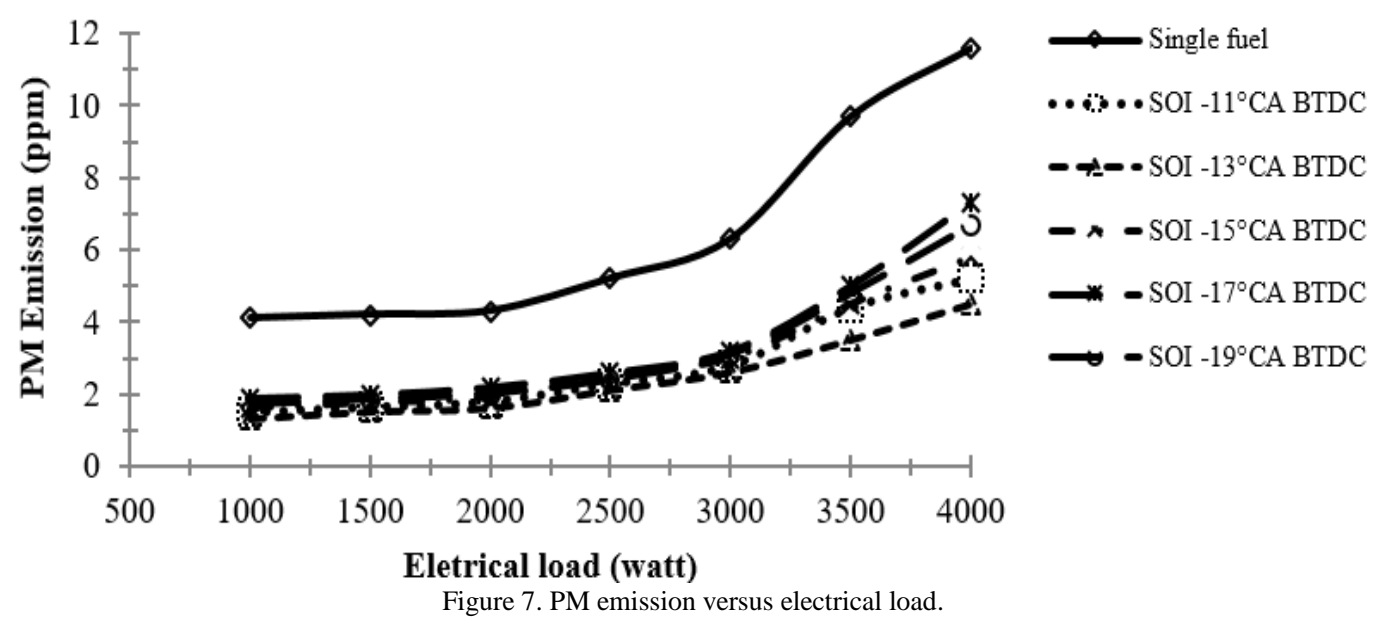

\section{CONCLUSION}

Based on the results of research then it can be concluded as follows: Advancing the diesel pilot injection time can increase engine power and BMEP there is no significant difference between DDF and single fuel. Advancing pilot injection timing can increase thermal efficiency by\% but compare to single fuel is still low.

Advancing pilot injection timing decreased of $\mathrm{CO}$ and $\mathrm{HC}$ emissions, respectively $26.67 \%$ and $42.86 \%$ and reduced the PM emissions by $68.29 \%$ compared to single fuel. As a result, the in-cylinder temperature increases, which may be the main reason $\mathrm{CO}$ and $\mathrm{HC}$ decrease.

\section{AKNOWLEDGEMENTS}

This article is one of the requirements to complete a postgraduate program at Institut Teknologi Sepuluh Nopember Surabaya. Do not forget to thank the DDF team of Mechanical engineering ITS.

\section{REFERENCES}

[1] D. Yuvenda and B. Sudarmanta, "Karakterisasi performa mesin sistem dual fuel menggunakan pressure reducer adaptive dengan variasi konstanta $(\mathrm{k})$ pegas helix tekan dan tekanan gas keluar pada stage dua,” in Prosiding Seminar Nasional Manajemen Teknologi XXIII, 2015, pp. 24.2-24.8.
[2] D. Yuvenda, B. Sudarmanta, and E. Alwi, "Analisis kekuatan pegas pressure reducer sebagai penurunan tekanan pada mesin duel fuel," INVOTEK J. Inov. Vokasional dan Teknol., vol. 17, no. 2, pp. 3138, Nov. 2017.

[3] D. Y. Exoryanto and B. Sudarmanta, "Studi eksperimen unjuk kerja mesin diesel menggunakan sistem dual fuel solar gas CNG Dengan Variasi Tekanan injeksi gas dan derajat waktu injeksi,” J. Tek. ITS, vol. 5, no. 2, pp. 604-609, Feb. 2017.

[4] B. Yang, C. Xi, X. Wei, K. Zeng, and M.-C. Lai, "Parametric investigation of natural gas port injection and diesel pilot injection on the combustion and emissions of a turbocharged common rail dual-fuel engine at low load,” Appl. Energy, vol. 143, pp. 130-137, Apr. 2015.

[5] R. . Papagiannakis and D. . Hountalas, "Combustion and exhaust emission characteristics of a dual fuel compression ignition engine operated with pilot Diesel fuel and natural gas," Energy Convers. Manag., vol. 45, no. 18-19, pp. 2971-2987, Nov. 2004.

[6] B. Yang, L. Wang, L. Ning, and K. Zeng, "Effects of pilot injection timing on the combustion noise and particle emissions of a diesel/natural gas dual-fuel engine at low load," Appl. Therm. Eng., vol. 102, pp. 822-828, Jun. 2016.

[7] R. G. Papagiannakis, S. R. Krishnan, D. C. Rakopoulos, K. K. Srinivasan, and C. D. Rakopoulos, "A combined experimental and theoretical study of diesel fuel injection timing and gaseous fuel/diesel mass ratio effects on the performance and emissions of natural gas-diesel HDDI engine operating at various loads," Fuel, vol. 202, pp. 675-687, Aug. 2017. 